\title{
ANALISIS KADAR MERKURI (Hg) PADA TANAMAN PADI (Oryza sativa L.) DI AREA PERSAWAHAN DESA GRANDENG KECAMATAN LOLONG GUBA PULAU BURU
}

\author{
W. P. Suci ${ }^{1 *}$, A. Mariwiy ${ }^{1}$, J. B. Manuhuttu ${ }^{1}$ \\ ${ }^{1}$ Departement of Chemistry-FKIP, Pattimura University Ambon \\ ”purnamasuciwiwin@gmail.com
}

\begin{abstract}
The research to analysis the content of mercury $(\mathrm{Hg})$ on soil and root of rice in rice fields of Grandeng Village Lolong Guba Sub-district, Buru Island. The dry sample was prepared by putting it in an oven at $40^{\circ} \mathrm{C}$ for two days and then destruction it. To analysis the mercury on this research used Cold Vapor AAS analysis methods. The results showed that the average content of $\mathrm{Hg}$ on soil was $77.897 \mathrm{ppm}$ and the average content of $\mathrm{Hg}$ on rice root was $10,813 \mathrm{ppm}$. Based on the results of the analysis showed that on rice plants in the rice fields of Grandeng Village it has exceeded the threshold that determined by Center of Geological Resources which is in paddy soils of $0,005 \mathrm{ppm}$ and the threshold allowed by Indonesia National Agency of Drug and Food Control (NADFC) to consume rice is $0,3 \mathrm{ppm}$.
\end{abstract}

Keywords: Mercury (Hg), Buru Island, Cold Vapor-AAS, Rice Plant.

\section{ABSTRAK}

Telah dilakukan penelitian untuk menganalisis kandungan merkuri $(\mathrm{Hg})$ pada Tanah dan Akar Padi di area Persawahan Desa Grandeng Pulau Buru. Sampel kering dipreparasi dengan cara dimasukkan ke dalam oven dengan suhu $40^{\circ} \mathrm{C}$ selama dua hari dan kemudian dilakukan destruksi. Analisis merkuri pada penelitian ini dilakukan dengan metode analisis menggunakan SSA - Uap Dingin. Hasil penelitian menunjukan bahwa kandungan rata-rata $\mathrm{Hg}$ pada Tanah yaitu sebesar 77,897 ppm dan kandungan rata-rata $\mathrm{Hg}$ pada Akar Padi yaitu sebesar 10,813 ppm. Dapat dilihat bahwa berdasarkan hasil analisis yang diperoleh pada tanaman padi yang berada di area persawahan Desa Grandeng telah melebihi ambang batas yang ditetapkan menurut Pusat Sumber Daya Geologi yakni pada Tanah sawah sebesar 0,005 ppm dan ambang batas yang diperbolehkan oleh Badan Pengawasan Obat dan Makanan (BPOM) untuk mengkonsumsi beras sebesar 0,3 ppm.

Kata kunci: Merkuri (Hg), Pulau Buru, SSA-Uap Dingin, Tanaman Padi.

\section{PENDAHULUAN}

Usaha pertambangan emas oleh sebagian masyarakat sering dianggap sebagai penyebab kerusakan dan pencemaran lingkungan (Raharjo, dkk., 2012). Salah satu penyebab pencemaran lingkungan oleh merkuri adalah pembuangan limbah pengolahan emas yang diolah secara amalgamasi. Proses amalgamasi adalah pengikatan emas dengan menggunakan merkuri (Widodo, 2008). Dalam kegiatan tersebut dibutuhkan aliran air untuk memisahkan batuan halus dengan amalgam (campuran merkuri dan emas) yang dialirkan ke kolam penampungan limbah (Irsyad, 2014).

Gunung Nona Pulau Buru, merupakan salah satu daerah penghasil sumber daya alam berupa emas yang cukup melimpah. Eksploitasi emas secara illegal di daerah tersebut dimulai Tahun 2014. Gunung Nona berada di Desa Wapsalit Kecamatan Lolongguba Kabupaten Buru serta 
terletak pada hulu sungai Wai Pamali. Sungai Wai Pamali mengalir ke waduk Pamali yang kemudian di manfaatkan oleh masyarakat Desa Grandeng untuk irigasi persawahan. Akar semua tanaman yang tumbuh di sawah telah menyerap limbah tambang ini (Kompas, 2016).

Merkuri yang terbuang ke aliran sungai sebagai sisa dari proses amalgamasi akibat aktivitas pertambangan emas akan mengalami proses metilasi dengan bantuan bakteri. Persenyawaan merkuri yang terdapat dalam air dan endapan dasar perairan oleh aktivitas kehidupan bakteri akan diubah menjadi $\mathrm{Hg}^{2+}$ dan $\mathrm{HgO}$. Logam yang dihasilkan oleh aktivitas bakteri ini karena faktor fisik dapat menguap ke udara, namun pada akhirnya merkuri yang menguap akan kembali ke perairan oleh hujan (Palar, 1994). Efek toksisitas merkuri tergantung pada bentuk merkuri, jalan masuk ke dalam tubuh, dan lamanya berkembang. Masyarakat yang tinggal di sekitar aliran sungai yang merupakan tempat pembuangan limbah pengolahan emas biasanya mengalami keracunan merkuri jenis metil merkuri dan masuk ke tubuh melalui jalur pencernaan (Alfian, 2006). Berdasarkan latar belakang yang telah diuraikan maka penulis merasa tertarik untuk melakukan penelitian dengan judul "Analisis Kadar Merkuri (Hg) Pada Tanaman Padi (Oriza Sativa L.) di Area Persawahan Desa Grandeng Kecamatan Lolong Guba Pulau Buru”.

\section{METODE PENELITIAN}

Penelitian ini di laksanakan pada laboratorium kimia Anorganik FMIPA Unpatti Ambon meliputi penyiapan sampel, dekstruksi sampel dan identifikasi merkuri pada sampel, untuk pengukuran kadar $\mathrm{Hg}$ di laksanakan di Laboratorium Baristand Manado.

1. Penentuan Lokasi Dan Pengambilan Sampel

Penentuan titik lokasi pengambilan sampel dilakukan dengan menggunakan GPS pada tiga titik lokasi berbeda. Setelah itu dilakukan pengukuran parameter fisika dan kimia. Pengambilan sampel tanah diambil pada kedalaman 10-20 cm kemudian dimasukkan dalam plastik sampel dan disimpan dalam cool box yang telah berisi es batu. Pengambilan sampel akar padi diambil dengan cara mencabut tanaman padi yang siap dipanen. Sampel yang diperoleh ini kemudian dimasukkan ke dalam plastik sampel dan diletakkan dalam cool box.

2. Penyiapan Sampel

Sampel tanah (S1, S2 dan S3) masing-masing dipisahkan dari pengotor (pasir, batu, kayu dll), ditimbang berat awal, kemudian dikeringkan di dalam oven pada suhu $40^{\circ}$ selama dua hari digerus dan ditimbang berat masing-masing sampel. Sampel akar padi (S1, S2 dan S3) masing-masing dipisahkan dari pengotor, dibilas dengan akuades, ditimbang berat awal masing-masing sampel, dikeringkan didalam oven pada suhu $40^{\circ}$ selama dua hari. Kemudian masing-masing sampel digerus sampai halus dan ditimbang berat masing-masing sampel.

3. Dekstruksi Sampel Tanah dan Akar Padi

Dalam proses destruksi sampel tumbuhan, yang pertama dilakukan yaitu akar yang telah dihaluskan ditimbang sebanyak 2 gram dan dimasukan dalam labu alas bulat $250 \mathrm{ml}$. Setelah itu ditambahkan berturut - turut $30 \mathrm{ml}$ larutan $\mathrm{HNO}_{3}$ pekat $65 \%$ dan $10 \mathrm{ml}$ larutan $\mathrm{H}_{2} \mathrm{SO}_{4}$ pekat $95 \%$ sedikit demi sedikit. Larutan yang sudah tercampur kemudian dipanaskan pada suhu $100^{\circ} \mathrm{C}$ selama satu jam dan ditambahkan $5 \mathrm{ml} \mathrm{H} \mathrm{O}_{2} 30 \%$ sedikit demi sedikit sampai larutannya bening. Fungsi $\mathrm{H}_{2} \mathrm{O}_{2}$ adalah sebagai agen pengoksidasi. Kemudian didinginkan dan di saring dengan kertas saring whatman. Setelah itu dilakukan pengukuran kadar logam Hg pada panjang gelombang 253.7 $\mathrm{nm}$ dengan menggunakan AAS.

Pada proses destruksi sampel tanah, yang pertama dilakukan yaitu menimbang tanah yang telah digerus sebanyak 2 gram dan ditambahkan $\mathrm{HNO}_{3}: \mathrm{HCl}$ pekat (3:1) sebanyak $10 \mathrm{ml}$ sambil diaduk. Setelah itu larutan dipanaskan pada suhu $100^{\circ} \mathrm{C}$ selama satu jam dan ditambahkan $5 \mathrm{ml}$ $\mathrm{H}_{2} \mathrm{O}_{2} 30 \%$ sedikit demi sedikit sampai larutannya bening. Setelah itu, didinginkan dan disaring 
dengan menggunakan kertas saring whatman. setelah itu dilakukan pengukuran kadar logam $\mathrm{Hg}$ pada panjang gelombang $253.7 \mathrm{~nm}$ dengan menggunakan AAS.

4. Pembuatan Larutan Standar $\mathrm{Hg}$

Larutan induk merkuri $1000 \mathrm{mg} / \mathrm{L}$, dibuat dengan cara menimbang $1,3539 \mathrm{~g} \mathrm{HgCl}_{2}$ anhidrat, dilarutkan dalam $\mathrm{HCl} 1 \mathrm{M}$ dan diencerkan hingga tanda batas. Selanjutnya diencerkan hingga 100 ppm. Larutan standar dibuat dari larutan induk merkuri $100 \mathrm{mg} / \mathrm{L}$ dengan cara larutan induk $\mathrm{Hg} 100$ ppm dipiet sebanyak $1 \mathrm{~mL}$. Kemudian dimasukkan kedalam labu takar $100 \mathrm{~mL}$, dan ditambahkan aquadest hingga tanda batas. Larutan ini mengandung larutan merkuri 1000 ppb. Kemudian dari larutan induk ini, dipipet sebanyak $1 \mathrm{~mL}$ dan dimasukkan kedalam labu takar $10 \mathrm{~mL}$. Larutan ditepatkan dengan akuades hingga tanda batas. Larutan ini mengandung larutan merkuri $100 \mathrm{ppb}$.

Pengenceran secara seri menjadi larutan standar merkuri dengan konsentrasi (ppb): $0: 10,00$ ; 20,00 dan 30,00 dengan cara memipet masing-masing $(\mathrm{mL}) 0,00 ; 0,10 ; 0,20$ dan 0,30 dari larutan merkuri $100 \mathrm{ppb}$. Kemudian dimasukkan masing-masing ke dalam labu takar $10 \mathrm{~mL}$ dan ditepatkan hingga tanda batas dengan dengan akuades. Laruan ini selanjutnya dituang dalam tabung reaksi dan ditambahkan $0,1 \mathrm{~mL} \mathrm{KMnO}_{4} 5 \%$, dikocok, ditambahkan lagi $0,1 \mathrm{~mL}$ hidroksilamin hidroklorida 10\%, dikocok, dan ditambahkan $0,5 \mathrm{~mL} \mathrm{SnCl} 210 \%$. Masing-masing larutan ini kemudian diukur serapannya pada panjang gelombang $253,7 \mathrm{~nm}$ dengan SSA - Uap dingin.

\section{HASIL PENELITIAN}

\section{A. Penentuan Titik Lokasi Pengambilan Sampel}

Sampel Tanah dan Akar Padi pada penelitian ini diambil pada area persawahan desa Grandeng, Kecamatan Lolongguba Kabupaten Buru pada bulan Januari tanggal 21, pengambilan sampel pada pukul 17.15 WIT dengan keadaan cuaca cerah berawan. Pemilihan tanah dan akar padi sebagai sampel pada penelitian ini dikarenakan tanah pada lahan sawah di Desa Grandeng menggukan air pada Waduk Pamali yang terhubung langsung dengan sumber pembuangan limbah merkuri sebagai sistem irigasi. Sedangkan alasan pemilihan akar dikarenakan akar merupakan bagian dari tumbuhan padi yang menyerap unsur hara dan logam yang terkandung didalam tanah persawahan, sebelum menyebarkan merkuri ke bagian tanaman padi lainnya.

Penentuan lokasi pengambilan sampel merupakan perlakuan awal dari penelitian ini. Titik lokasi pengambilan sampel dilakukan dengan menggunakan GPS pada tiga titik berbeda dalam satu sawah. Penentuan tiga titik lokasi pengambilan sampel ini untuk melihat pencemaran merkuri pada keseluruhan sawah tersebut. Tabel 1 Menunjukkan penentuan titik lokasi pengambilan sampel dan pengujian parameter fisika kimia sebelum pengambilan sampel dilakukan.

Tabel 1. Pengujian Parameter Fisika Kimia

\begin{tabular}{|c|c|c|c|}
\hline Kode Sampel & Koordinat Gps & $\mathrm{pH}$ & Suhu \\
\hline Sampel (S1) & S03027’542" E126054'678" & 7,3 & 27 \\
\hline Sampel (S2) & S03027’501" E126054'670" & 7,3 & 28 \\
\hline Sampel (S3) & S03027'490" E126054'670" & 7,5 & 27 \\
\hline
\end{tabular}

Berdasarkan Peraturan Pemerintah Republik Indonesia No 20 Tahun 2000 baku mutu pH tanah berkisar 4-7. $\mathrm{pH}$ sampel tanah yang diukur sebesar 7,3. $\mathrm{pH}$ ini telah melebihi ambang batas, $\mathrm{pH}$ diatas 7 mengakibatkan ion fosfat bereaksi $\mathrm{Mg}_{3}\left(\mathrm{PO}_{4}\right)_{2}$ yang sukar larut dalam air dan unsur hara fosfor (P) menjadi tidak tersedia dalam tanaman (Sudaryono, 2009). Ketidaksediaan unsur hara dalam tanah akan mengakibatkan pertumbuhan padi terhambat. Mimin (2013), pH 5-7 mengakibatkan konsentrasi $\mathrm{Hg}$ didalam tanah akan meningkat karena mobilitas raksa dari dalam tanah. Persamaan reaksi pembentukan $\mathrm{Ca}_{3}\left(\mathrm{PO}_{4}\right)_{2}$ dan $\mathrm{Mg}_{3}\left(\mathrm{PO}_{4}\right)_{2}$ dapat dilihat sebagai berikut: 


$$
\begin{aligned}
& 3 \mathrm{CaCl}_{2(\mathrm{aq})}+2 \mathrm{Na}_{3} \mathrm{PO}_{4(\mathrm{aq})} \rightarrow \mathrm{Ca}_{3}\left(\mathrm{PO}_{4}\right)_{2(\mathrm{aq})}+6 \mathrm{NaCl}_{(\text {aq })} \\
& 2 \mathrm{H}_{3} \mathrm{PO}_{4(\mathrm{aq})}+3 \mathrm{Mg}(\mathrm{OH})_{2(\mathrm{aq})} \rightarrow \mathrm{Mg}_{3}\left(\mathrm{PO}_{4}\right)_{2(\mathrm{aq})}+\mathrm{H}_{2} \mathrm{O}_{(\text {aq })}
\end{aligned}
$$

Suhu tanah berpengaruh terhadap pertumbuhan tanaman juga berdampak pada pelapukan batuan secara fisik dalam tanah (Buckman and Brady, 1982). Menurut Aak (1990), suhu tanah yang baik untuk tanaman padi adalah $20-25^{\circ} \mathrm{C}$. Pengukuran suhu pada tiga titik lokasi pengambilan sampel secara berturut-turut adalah 27,28 dan $27^{\circ} \mathrm{C}$. Berdasarkan data tersebut maka suhu tanah pada lokasi pengambilan sampel melebihi ambang batas yang telah ditetapkan.

Pengambilan sampel tanah diambil pada kedalaman $10-20 \mathrm{~cm}$. Hal ini sejalan dengan pernyataan Bobihoe (2007) bahwa pengolahan tanah terhadap padi yang dipanen biasanya pada kedalaman 10-20 cm dan lebihnya. Menurut Chen et al., (2012), tingkat tertinggi pencemaran merkuri terjadi di kedalaman $0-20 \mathrm{~cm}$ lapisan tanah dan mengalami penurunan dari permukaan kebawah lapisan tanah. Sedangkan, pengambilan sampel akar padi diambil dengan cara mencabut tanaman padi yang siap dipanen. Menurut Nurshidika, dkk., (2014) bahwa pengambilan sampel padi dilakukan pada padi siap panen, karena pada saat itu padi akan diproses menjadi beras sehingga dapat dikonsumsi.

\section{B. Penyiapan Sampel}

Sampel tanah (S1, S2 dan S3) dibersihkan dengan cara memisahkan zat pengotor dari sampel. Zat pengotor tersebut dapat berupa batu, batang kayu. Sedangkan sampel akar padi (S1, S2 dan S3) yang diperoleh dicuci dengan akuades yang bertujuan untuk membersihkan akar padi dari zat pengotor (Fahmi dan Ronaldi, 2013). Kemudian sampel yang telah dibersihkan dipotong dan ditimbang sebagai berat awal, dengan berat sampel S1, S2 dan S3 pada sampel tanah dan akar padi secara berturut-turut yaitu 72,$4256 ; 65,8769 ; 86,9743$ gram dan 7,$4536 ; 9,0508 ; 7,5234$ gram.

Sampel yang telah ditimbang kemudian dimasukkan ke dalam oven pada suhu $40^{\circ} \mathrm{C}$ selama dua hari. Proses ini bertujuan untuk mengeringkan sampel, dan menghilangkan kadar air dalam sampel sebelum dilakukan destruksi. Suhu di atas $25^{\circ} \mathrm{C}$ akan mengakibatkan merkuri akan menguap sehingga mempengaruhi hasil penelitian, tetapi jika merkuri terikat pada senyawa lain maka memerlukan titik didih yang tinggi (Malle, 2013). Selanjutnya sampel digerus dan ditimbang, dengan berat masing-masing sampel tanah dan akar padi (S1, S2, dan S3) berturut-turut yaitu : 61,$8012 ; 53,1343 ; 73,4677$ gram dan 6,$0893 ; 7,9301 ; 6,2976$ gram.

\section{Dekstruksi Sampel Tanah dan Akar Padi}

Proses destruksi diawali dengan menimbang sampel tanaman padi dan dilarutkan dalam larutan $\mathrm{HNO}_{3}: \mathrm{HCl}$. Penggunaan larutan asam klorida dan asam nitrat bertujuan untuk meningkatkan efisiensi ekstraksi logam berat merkuri dalam sampel tanah dan akar padi (Susila, 2012). Reaksi antara asam nitrat dengan asam klorida adalah sebagai berikut:

$$
3 \mathrm{HCl}_{(\text {(aq) }}+\mathrm{HNO}_{3(\mathrm{aq})} \rightarrow \mathrm{Cl}_{2(\mathrm{~g})}+\mathrm{NOCl}_{(\mathrm{g})}+2 \mathrm{H}_{2} \mathrm{O}_{(\mathrm{l})}
$$

Setelah itu, larutan dipanaskan pada suhu $100{ }^{\circ} \mathrm{C}$ selama satu jam dengan tujuan mempercepat reaksi yang terjadi antara sampel tailing dengan larutan asam. Kemudian ditambahkan $5 \mathrm{~mL} \mathrm{H} \mathrm{O}_{2} 30 \%$ hingga warna pada larutan menghilang. Penggunaan $\mathrm{H}_{2} \mathrm{O}_{2}$ dapat meningkatkan kemampuan oksidasi serta meningkatkan kinerja disolusi dari asam nitrat (Anderson, 1991). Reaksi yang terjadi yaitu sebagai berikut:

$$
\mathrm{HgCl}_{(\mathrm{g})}+\mathrm{NOCl}_{(\mathrm{g})}+2 \mathrm{H}_{2} \mathrm{O}_{(\mathrm{l})} \rightarrow \mathrm{Hg}^{2+}(\mathrm{g})+2 \mathrm{H}_{2} \mathrm{O}_{(\mathrm{l})}+4 \mathrm{OH}_{(\mathrm{aq})}+\mathrm{Cl}_{(\mathrm{g})}+\mathrm{NOCl}_{(\mathrm{g})}
$$


Larutan kemudian didinginkan dan disaring untuk memisahkan filtrat dengan residu dan dilakukan pengujian kadar logam $\mathrm{Hg}$ pada panjang gelombang $253,7 \mathrm{~nm}$ dengan menggunakan SSA-Uap dingin (Michelle, 2013).

\section{Pembuatan Kurva Baku dan Pembacaan Sampel}

Kurva kalibrasi didapat dari hasil serapan larutan standar terhadap konsentrasi yang sudah ditentukan sehingga dari kurva ini akan diperoleh suatu persamaan regresi. Pembuatan kurva baku (standar) pada penelitian ini diawali dengan membuat larutan standar merkuri $(\mathrm{Hg})$ untuk mengukur tingkat ketelitian data. Larutan standar, diencerkan dari larutan induk merkuri dengan teliti dan hatihati, agar kesalahan dalam pengenceran relatif kecil. dengan mengencerkan larutan induk 1000 ppm menjadi $0: 10,00: 20,00$ dan $30,00 \mathrm{ppb}$. Pengenceran dilakukan dengan menggunakan larutan induk $\mathrm{Hg} 1000$ ppm dengan hati-hati agar mengurangi tingkat kesalahan pengenceran.

Larutan standar yang diperoleh kemudian ditambahkan larutan $\mathrm{KMnO}_{4}$. Pengujian larutan standar $\mathrm{Hg}$ menggunakan larutan kalium permanganat berfungsi sebagai oksidator yang akan mengoksidasi senyawa merkuri klorida menjadi ion merkuri (II) (Nasir, 2013). Reaksi larutan standar $\mathrm{Hg}$ dengan $\mathrm{KMnO}_{4}$ dapat dilihat sebagai berikut :

$$
2 \mathrm{KMnO}_{4(\mathrm{aq})}+\mathrm{HgCl}_{2(\mathrm{aq})} \rightarrow 2 \mathrm{MnO}_{4}^{-}(\mathrm{aq})+\mathrm{Hg}^{2+}{ }_{(\mathrm{aq})}+2 \mathrm{KCl}_{(\mathrm{aq})}
$$

Berdasarkan reaksi di atas, dapat dilihat bahwa reaksi antara larutan standar $\mathrm{Hg}$ dengan $\mathrm{KMnO}_{4}$ menghasilkan permanganat yang berlebih untuk menghilangkan (menghancurkan) permanganat berlebih tersebut digunakan hidroksilamin hidroklorida. Selain bertujuan untuk menghilangkan $\mathrm{KMnO}_{4}$, hidroksilamin hidroklorida juga bertujuan untuk menghilangkan warna pada larutan. Reaksi $\mathrm{MnO}_{4}$ - dengan $\mathrm{H}_{2} \mathrm{NOH} . \mathrm{HCl}$ (Hidroksilamin Hidroklorida) dapat dilihat sebagai berikut $12 \mathrm{MnO}_{4^{-}(\mathrm{aq})}+6 \mathrm{H}_{2} \mathrm{NOH} \cdot \mathrm{HCl}_{(\mathrm{aq})} \rightarrow 12 \mathrm{HMnO}_{4(\mathrm{aq})}+6 \mathrm{H}_{2} \mathrm{O}_{(\mathrm{l})}+6 \mathrm{~N}_{2(\mathrm{~g})}+6 \mathrm{Cl}_{(\mathrm{aq})}^{-}$ berikut :

Setelah itu larutan standar $\mathrm{Hg}$ ditambahkan dengan larutan $\mathrm{SnCl}_{2}$, dengan reaksi sebagai

$$
\mathrm{Hg}^{2+}(\mathrm{aq})+\mathrm{SnCl}_{2}(\mathrm{aq}) \rightarrow \mathrm{Hg}(\mathrm{g})+\mathrm{Sn}^{4+}(\mathrm{aq})+2 \mathrm{Cl}(\mathrm{aq})
$$

Penggunaan larutan $\mathrm{SnCl}_{2}$ digunakan sebagai pereduksi untuk mengurangi ion merkuri pada raksa. Selanjutnya larutan standar Hg diukur serapannya dengan SSA-Uap dingin. setelah proses analisis maka akan ditampilkan hasil absorbansi standar yang terbaca, seperti ditunjukan pada Tabel 2.

Tabel 2. Data Hasil Pengukuran Absorbansi Larutan Standar Hg

\begin{tabular}{cc}
\hline $\begin{array}{c}\text { Konsentrasi Larutan } \mathrm{Hg} \\
(\mathrm{ppb})\end{array}$ & Absorbansi \\
\hline 0,0 & 0,0008 \\
10,0 & 0,0301 \\
20,0 & 0,0765 \\
30,0 & 0,0971 \\
\hline
\end{tabular}

Berdasarkan data pada Tabel 2, maka dibuat kurva standar hubungan absorbansi terhadap konsentrasi larutan $\mathrm{Hg}$ yang dapat dilihat pada Gambar 1. 


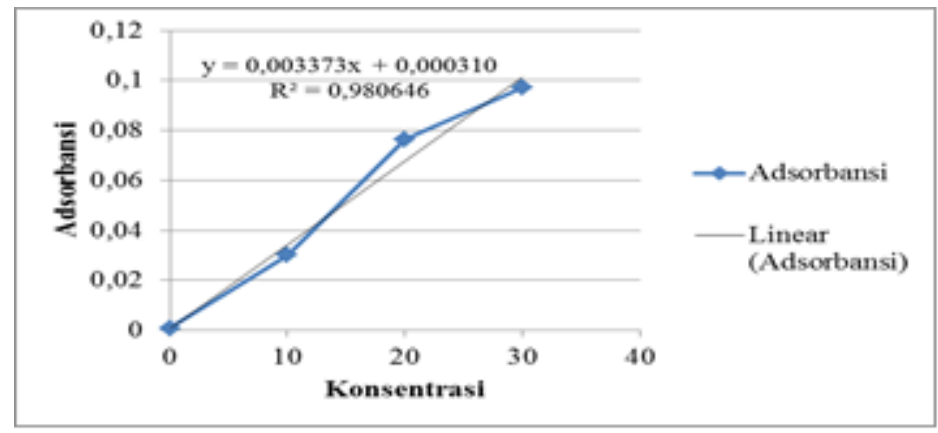

Gambar 1. Kurva Standar Larutan Hg

Berdasarkan kurva kalibrasi, diperoleh persamaan regresi $y=0,003373 x+0,000310$, dengan nilai $R^{2}=0,980646$. Kurva ini menunjukkan bahwa koefisien korelasi dari variasi konsentrasi terhadap serapan mempunyai hubungan. Semakin tinggi konsentrasi maka semakin tinggi pula absorbansinya.

\section{E. Akumulasi Merkuri (Hg) Pada Akar Padi dan Tanah}

Sampel yang telah dipreparasi kemudian dianalisis untuk mengetahui seberapa besar kadar merkuri yang terakumulasi pada akar padi dan tanah. Analisis kandungan merkuri pada akar padi dan tanah dilakukan dengan menggunakan Spektrofotometer Serapan Atom Uap Dingin. Pemilihan padi sebagai sampel penilitian dikarenakan selaian padi merupakan tanaman pangan atau tanaman pokok yang dikonsumsi masyarakat indonesia, padi juga adalah tanaman hipertoleransi tetapi bukan tanaman hiperakumulator. Karena padi mampu mentoleransi kandungan logam berat yang diserapnya. Data hasil analisis kandungan merkuri pada akar padi dan tanah dapat dilihat pada Tabel 3.

Tabel 3. Hasil Analisis Kandungan Merkuri ( $\mathrm{Hg})$ Pada Tanaman Padi

\begin{tabular}{|c|c|c|c|c|c|c|}
\hline $\begin{array}{l}\text { Kode } \\
\text { Sampel }\end{array}$ & Sampel & Absorbansi & $\begin{array}{c}\text { Konsentrasi } \\
\text { Baca } \\
(\mu \mathrm{g} / \mathrm{L}) \\
\end{array}$ & $\begin{array}{c}\text { Konsentrasi } \\
\text { Akhir } \\
(\mathrm{ppm}) \\
\end{array}$ & $\begin{array}{c}\mathrm{Hg} \\
\text { Rata-rata } \\
\text { (ppm) } \\
\end{array}$ & $\begin{array}{c}\mathrm{Hg} \\
\text { Rata-rate } \\
(\mathrm{ppb})\end{array}$ \\
\hline \multirow{3}{*}{ Tanah } & S1 & 0.0867 & 25,574 & 192,78 & \multirow{3}{*}{77,897} & \multirow{3}{*}{77897} \\
\hline & S2 & 0.0175 & 5,089 & 25,89 & & \\
\hline & S3 & 0.0067 & 1,892 & 15,02 & & \\
\hline \multirow{3}{*}{ Akar Padi } & S1 & 0.0053 & 1,477 & 14,58 & \multirow{3}{*}{10,813} & \multirow{3}{*}{10813} \\
\hline & S2 & 0.0051 & 1,418 & 13,64 & & \\
\hline & S3 & 0.0019 & 0,471 & 4,22 & & \\
\hline
\end{tabular}

Berdasarkan Tabel 3 dapat dilihat bahwa konsentrasi merkuri di tanah sawah pada sampel berbeda-beda, dengan konsentrasi yang melebihi nilai ambang batas (NAB) merkuri pada tanah menurut pusat sumber daya geologi (dalam Sugianti, 2014) menetapkan konsentrasi kandungan merkuri yang diijinkan pada tanah yaitu 0,005 ppm.

Perbedaan konsentrasi merkuri pada tiap lokasi dikarenakan jarak pengambilan sampel yang berbeda-beda dengan lokasi pertambangan. Jarak terdekat hingga terjauh pada tiap sampel terhadap lokasi pertambangan secara berturut-turut yaitu S1, S2 dan S3. Konsentrasi merkuri tertinggi yaitu pada sampel tanah sebesar 192,78 dan sampel akar padi sebesar 14,58 ppm. Hal ini dikarenakan dekatnya jarak S1 dengan lokasi pertambangan sehingga memungkinkan konsentrasi Hg lebih banyak dibandingkan sampel S2 dan S3. 
Tingginya konsentrasi $\mathrm{Hg}$ total dalam tanah dapat terserap ke dalam tanaman padi. Tanaman padi yang diambil sebagai sampel merupakan tanaman padi yang telah memasuki masa panen. Usia tanaman pada saat pengambilan sampel adalah 6 bulan. Jika dilihat dari rata-rata konsentrasi total $\mathrm{Hg}$ di ketiga sampel akar padi (Tabel 3), dapat diketahui bahwa semakin jauh jarak sawah dengan sistem irigasi, konsentrasi total $\mathrm{Hg}$ semakin menurun. Hal ini menunjukkan kemungkinan adanya pengaruh kegiatan amalgamasi terhadap pencemaran $\mathrm{Hg}$ pada tanah dan tanaman.

\section{KESIMPULAN}

Berdasarkan pembahasan dan tujuan penelitian ini maka, dapat ditarik kesimpulan bahwa rata-rata kandungan merkuri terakumulasi dalam tanah sawah sebesar $77,897 \mathrm{ppm}$, hal ini menunjukkan bahwa kandungan merkuri pada tanah sawah desa grandeng kecamatan lolongguba pulau buru telah melebihi ambang batas yang ditetapkan oleh Pusat Sumber Daya Geologi yaitu sebesar 0,005 ppm sedangkan rata-rata kandungan merkuri terakumulasi dalam akar padi sebesar $10,813 \mathrm{ppm}$, hal ini menunjukkan bahwa tanaman padi telah melebih ambang batas yang ditetapkan oleh Badan Pengawasan Obat dan Makanan (BPOM) untuk tanaman pangan layak dikonsumsi yakni sebesar 0,3 ppm.

\section{DAFTAR PUSTAKA}

Aak. (1990). Budidaya Tanaman Padi. Penerbit Kanisius: Yogyakarta.

Alfian, Z. (2006). Merkuri: Antara Manfaat Dan Efek Penggunaannya Bagi Kesehatan Manusia dan Lingkungan. USU E-Repository. Medan: Universitas Sumatera Utara.

Anderson, R. (1991). Sample Pretreatment and Separation. New York: John Willey \& Sons.

Bobihoe Julistia. (2007). Inovasi Teknologi Untuk Meningkatkan Produktivitas Tanaman Padi. Balai Pengkajian Teknologi Pertanian : Jambi.

Buckman, H. O. and Brady, N. C. (1982). Ilmu tanah (terjemahan Soegiman). Bharatara Karya Aksara: Jakarta.

Chen, El. et al., (2012). Spatial Trend and Polution Assessment of total mercury and methyl mercury polution in the pearl river delta soil. South China. Chemosphere: 1-8.

Irsyad Muhammad. (2014). Translokasi Merkuri $(\mathrm{Hg})$ Pada Daun Tanaman Bayam Duri (Amaranthus Spinosus L) Dari Tanah Tercemar. Jurnal Of Natural Science. Vol.3 (1): 817.

Kompas. (04 Desember 2016). Merkuri Cemari Sawah. disitasi pada tanggal 05 Desember 2014 dari kompasprint.com

Male, Y. T. Reichelt-Brushett A. J. Pocock M \& Nanlohy A. (2013). Recent Mercury Contamination From Artisanal Gold Mining On Buru Island, Indonesia - Potential Future Risks To Environmental Health And Food Safety. Marine Pollution Bulletin. Vol. 77(1-2) 428-433.

Margaret Sidarta Michelle. (2013). Validasi metode analisis unsur logam pb, cu, dan zn Produk saus tomat $z$ dari pasar tradisional a Di kota solo dengan icps. Jurnal Ilmiah Mahasiswa Universitas Surabaya .Vol.2 No.2.

Mimin. (2013). Dampak Pencemaran Merkuri (Hg) Terhadap Lingkungan. Jurnal Lingkungan Hidup Daerah Provinsi Manado. Vol 2, No $4: 221$.

Nasir, Moh. (2013). Metode Penelitian. Bogor: Ghalia Indonesia.

Nursidika Perdina. (2014). Kandungan Timbal Pada Air dan Padi di Daerah Industri Leuwigajah Cimahi. Jurnal Kesehatan Kartika.Vol. 9 No. 1. Hal : 19.

Palar, H. (1994). Pencemaran dan Toksikologi Logam Berat. Rineka Cipta, Jakarta. 
Sudaryono. (2009). Tingkat Kesuburan Tanah Ultisol pada Lahan Pertambang Baturbara Sangatta. Kalimantan Timur. Jurnal Teknik Lingkungan. 10(3). 337-346 hal.

Sugianti, Titin dkk., (2014). Penyebaran cemaran merkuri pada tanah sawah dampak pengolahan emas tradisional di pulau lombok NTB. prosiding nasional lahan suboptimal. Palembang 26-27 September. ISBN: 979-587-259-9, 227.

Widodo. (2008). Pengaruh perlakuan amalgamasi terhadap tingkat perolehan emas dan kehilangan merkuri, Jurnal RISET Geologi dan Pertambangan. Vol. 18(1) Hal: 47 - 54. 